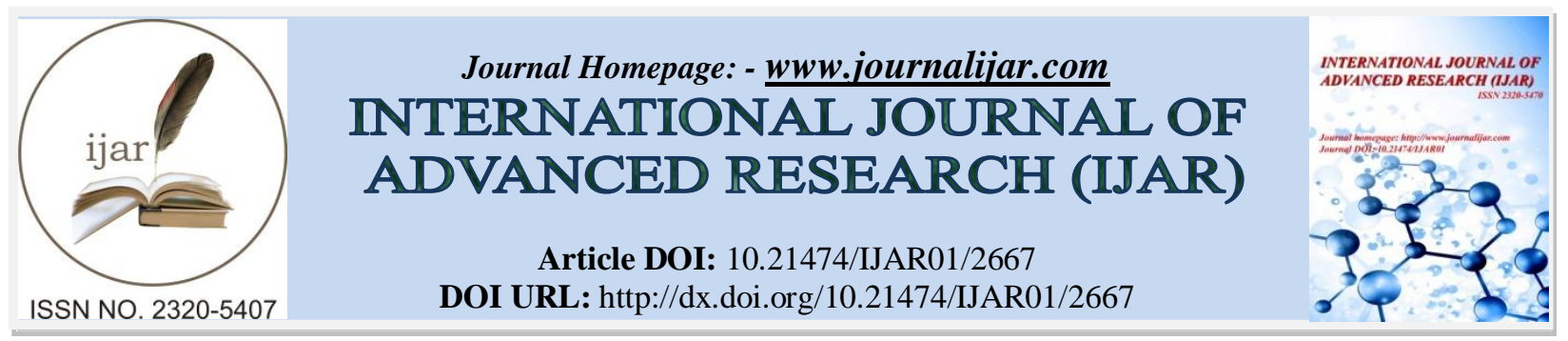

RESEARCH ARTICLE

\title{
SOCIAL INDICATORS OF SCHEDULED CASTE: A SOCIALLY EXCLUDED GROUP OF UTTARAKHAND.
}

Manisha Shah and J.C. Joshi.

Department of History, H.N.B. Garhwal University (A Central University) Campus Tehri Garhwal

\section{Manuscript Info}

\section{Manuscript History}

Received: 31 October 2016

Final Accepted: 30 November 2016

Published: December 2016

Key words:

Social exclusion, Scheduled caste, Social Indicators, Inequality, Educational

Level, Sex Ratio, Atrocities

\section{Abstract}

The present research paper deals with the study of some social indicators of scheduled caste in Uttarakhand. It has been noted that despite of various welfare measures adopted to improve their socioeconomic condition they still remain vulnerable and are subjected to various forms of atrocities committed against them. This inter-group inequalities are sharply marked with major contrast of social indicator i.e. income, education, health, employment and so on.

The contemporary understanding about social exclusion and social inequality has created interest among the academia and policy makers to understand the problems from the perspectives of the excluded groups. In an Indian context, exclusion is witnessed in various forms and it is much inter-related. It revolves around the axes of class, race, caste, religion, age, gender, tribal status, social position, occupational hierarchy and health status, physical or mental disable and so on. Inter-group disparities are sharply marked with major contrast of social, economic condition and cultural resources that is income, education, employment, housing, health and so on. These inequalities are more historically rooted and more structural in nature and have kept entire group or individual trapped in a cycle of social problems and unable them to take advantage of opportunities.

Thorat and Newman 2007 rightly pointed out that in Indian context exclusion is embedded in societal interrelations and institutions that discriminate, isolate, shamed and deprive subordinate groups on the basis of group identities like caste, religion, ethnicity and gender. India's historically rooted hierarchal social system plays a central role in the context of caste exclusion. Caste based exclusion prevent the disadvantaged groups from taking part in the full economic, social, religious and political life involving denial of equal opportunities, resources and rights of the community.

Social exclusion is the denial of equal opportunities imposed by certain groups of society upon others which leads to

inability of an individual to participate in the basic political, economic and social functioning of the society (Rao 2010).

Srinivas in 1962 defined caste as "a hereditary, endogamous group which is usually localised, it has a traditional association with an occupation and a particular position in the local hierarchy of castes. Relation between castes is governed among other things by the 
concept of purity and pollution and generally maximum commensality, i.e. inter-dinning occur between castes". This definition described the ideal form of caste system.

Copy Right, IJAR, 2016,. All rights reserved.

\section{Uttarakhand: A State Profile:-}

Uttarakhand is a state in the northern part of India amidst the magnificent Himalayas. The state was carved out from the hilly districts of Uttar Pradesh after mass agitations and given an independent status as the $10^{\text {th }}$ Himalayan state and the $27^{\text {th }}$ state of the Republic of India on $9^{\text {th }}$ November, 2000. The total geographical area of the state is about $53,483 \mathrm{sq} . \mathrm{km}$. The state is divided into two divisions, Garhwal and Kumaon, with a total of 13 districts, seven in Garhwal and six in Kumaon region.

\section{Socio-Demographic Profile:-}

The natives of the state are generally called Uttarakhandi or more specifically either Garhwali or Kumaoni depending on their place of origin. According to 2011 Census of India, population of Uttarakhand has reached approx 1.01 crore, making the $20^{\text {th }}$ most populous state in India with an increase of $19.17 \%$ from the past decade. The state feeds approx $0.84 \%$ of India's total population. The gender ratio is 963 females per 1000 males which were at 962 in 2001 Census and fares better as compared to average sex ratio of India at 940. As per the Census report 2011, it has literacy rate of $79.63 \%$ which is above the national average of $74.04 \%$ (Uttarakhand at a glance 2013-14).

\section{Decadal Changes in Demographic Indicators in Uttarakhand.}

\begin{tabular}{|l|l|l|}
\hline Indicators & Census 2001 & Census 2011 \\
\hline Population (in lakh) & 84.89 & 100.86 \\
\hline Male (in lakh) & 43.26 & 51.38 \\
\hline Female (in lakh) & 41.63 & 49.48 \\
\hline Density of Population & 159 & 189 \\
\hline Sex Ratio & 962 & 963 \\
\hline Child Sex Ratio (0-6 years) & 908 & 890 \\
\hline Literacy Rate in \% & 71.6 & 79.63 \\
\hline Literacy Rate (male) & 83.3 & 87.40 \\
\hline Literacy Rate (female) & 59.6 & 70.00 \\
\hline Gender Gap in Literacy in \% & 24 & 18 \\
\hline Decadal Growth Rate (1971-1981) $\mathbf{2 7 . 4 5 ~ \% ~}$ & \\
$\begin{array}{l}\text { Decadal Growth Rate (1981-1991) } \mathbf{2 4 . 2 3 ~ \% \% ~} \\
\text { Decadal Growth Rate (1991-2001) } \mathbf{1 9 . 3 4} \% \\
\text { Decadal Growth Rate (2001-2011) } \mathbf{1 9 . 1 7} \%\end{array}$ & \\
\hline
\end{tabular}

Source: Uttarakhand at a Glance 2013-2014, Directorate of Economics and Statistics, Dehradun, Govt. of Uttarakhand.

The state is the melting pot of many ethnic, religious groups and castes. Caste system, in the course of time, makes a unique feature in the society of the state since the very beginning when the inhabitants are settled up to the present time. The cultural composition of the state is constituted by the three castes, which are predominantly prevailed in the region. The society has mainly divided into three castes: Brahmans, Rajputs and Shilpkars or Kols or Doms.

\section{Caste Stratification in Uttarakhand:-}

Uttarakhand has a multiethnic population spread across two geo cultural regions the Garhwal and the Kumaon. The social structure of the region is characterized by deep social and economic inequalities. Inequalities can be attributed in part to state's particular social texture characterized by caste structures.

Caste system, geographical isolation, patriarchal society, superstitious believes, traditional system, illiteracy are some of the common malpractices which are still prevalent in society which create a major obstacles in the way of development. 


\section{Scheduled Caste: the most excluded group in Uttarakhand:-}

The Scheduled Caste (SCs) constitute as one of the most disadvantaged and stigmatized group of society and on this account, they suffer from numerous disabilities and lead the life of servitudes which are regulated through religious beliefs and practices. They have been the victims of social exclusion, economic exploitation and political oppression for several centuries.

The status of SCs in the newly formed hill state of India somewhat shows a silver lining in comparison with the rest of the country. Inspite of the constitutional provisions and welfare schemes, the SCs and more especially the untouchable castes in the State could never assert their rights and privileges because of their social strata, economic dependence on higher castes, traditional beliefs, geographical isolation, unemployment, widespread illiteracy and intimidation. Various studies and surveys were conducted to scrutinize the condition of untouchable castes in India and it has been observed that Untouchability is still being practiced against Scheduled Castes in many parts of India with all its vigour and religiosity and the Garhwal and Kumaon hills were no exception to this.

The Constitution (Scheduled Castes) Order, 1950 published with the Ministry or Law Notification No. S.R.O. 385, dated the $10^{\text {th }}$ August, 1950, Gazette of India, Extraordinary, 1950, Part II, Section 3, page 163, Subs. by Act 29 of 2000, s. 24 and Fifth Schedule (w.e.f. 09.11.2000) notified Sixty Five (65) castes as a Scheduled Castes of Uttaranchal.

\section{Part XXIV - Uttaranchal}

\begin{tabular}{|c|c|c|}
\hline 1. Agariya & 23. Boria & 45. Kharaita \\
\hline 2. Badhik & 24. Chamar, Dhusia, Jhusia, Jatav & 46. Kharwar \\
\hline 3. Badi & 25. Chero & 47. Khatik \\
\hline 4. Baheliya & 26. Dabgar & 48. Kharot \\
\hline 5. Baiga & 27. Dhangar & 49. Kol \\
\hline 6. Baiswar & 28. Dhanuk & 50. Kori \\
\hline 7. Bajaniya & 29. Dharkar & 51. Korwa \\
\hline 8. Bajgi & 30. Dhobi & 52. Lalbegi \\
\hline 9. Balhar & 31. Dom & 53. Majhwar \\
\hline 10. Balai & 32. Domar & 54. Mazhabi \\
\hline 11. Balmiki & 33. Dusadh & 55. Musahar \\
\hline 12. Bangali & 34. Dharmi & 56. Nat \\
\hline 13. Banmanus & 35. Dhariya & 57. Pankha \\
\hline 14. Bansphor & 36. Gond & 58. Parahiya \\
\hline 15. Barwar & 37. Gwal & 59. Pasi, Tarmali \\
\hline 16. Basor & 38. Habura & 60. Patari \\
\hline 17. Bawariya & 39. Hari & 61. Sahariya \\
\hline 18 Beldar & 40. Hela & 62. Sanaurhiya \\
\hline 19. Beriya & 41. Kalabaz & 63. Sansiya \\
\hline 20. Bhantu & 42. Kanjar & 64. Shilpkar \\
\hline 21. Bhuiya & 43. Kapariya & 65. Turaiha \\
\hline 22. Bhuyiar & 44. Karwal & \\
\hline
\end{tabular}

Source: Ins. by Act 29 of 2000, Section 24 and the Fifth Schedule (w.e.f. 09.11.2000)

\section{Population: Size and Distribution:-}

According to Uttaranchal data highlights of the Scheduled Castes 2001 Census of India, Economic and Statistical Directorate (2014-15) and Oxfam India (2010), the total population of the thirteen districts of Uttarakhand is $8,489,349$ out of these 1,517,186 persons are Scheduled Castes (SCs), which constitute 17.9\% of the total population of the state. The state has registered decadal growth of 23.2\% in SC population in 1991-2001 and as per Census 2011 out of the total population of 10,086,292 of the state the SCs are 1,892,516 persons comprises male $\mathbf{9 6 8 , 5 8 6}$ and female $\mathbf{9 2 3 , 9 3 0}$ which constitute of $18.76 \%$. 
Rural Urban Distribution of Scheduled Castes 2001

\begin{tabular}{|l|l|l|l|l|}
\hline Scheduled Castes & Population & Male & Female & Literacy Rate in \% \\
\hline Total & $1,517,186$ & 780,772 & 736,414 & 63.40 \\
\hline Rural & $1,256,122$ & 642,087 & 614,035 & 61.53 \\
\hline Urban & 261,064 & 138,685 & 122,379 & 72.01 \\
\hline
\end{tabular}

Source: Statistical Diary 2001-2002, Directorate of Economics and Statistics, Dehradun, Govt. of Uttarakhand.

In a same reference data of 2001 Census figured out that the individual Scheduled Caste wise, Shilpkar in majority alone have a population of (51.9\%) of the state SCs population, followed by Chamar (29.3\%), Balmiki (5.9\%), Kori (2.7\%), Bajgi (1.4\%) and Dom (1.2\%). The Pasi, Dhobi and Kol are the three other SCs, each having returned more than 10,000 populations. The rest of the SCs are small in population size. The table below depicts the population and proportion of some major SCs in a state.

Population and Proportion of Major SCs (2001 Census).

\begin{tabular}{|l|l|l|l|}
\hline S. No. & Scheduled Caste & Total Population & $\begin{array}{l}\text { Proportion to the total SC } \\
\text { population } \%\end{array}$ \\
\hline 1 & All Scheduled Caste & $\mathbf{1 , 5 1 7 , 1 8 6}$ & $\mathbf{1 0 0}$ \\
\hline 2 & Shilpkar & 786,883 & 51.9 \\
\hline 3 & Chamar & 444,612 & 29.3 \\
\hline 4 & Balmiki & 89,348 & 5.9 \\
\hline 5 & Kori & 40,304 & 2.7 \\
\hline 6 & Bajgi & 20,805 & 1.4 \\
\hline 7 & Dom & 18,720 & 1.2 \\
\hline 8 & Pasi & 14,400 & 0.9 \\
\hline 9 & Dhobi & 14,195 & 0.9 \\
\hline 10 & Kol & 13,338 & 0.9 \\
\hline
\end{tabular}

Source: Office of the Registrar General, India, page 1 of 5

\section{Sex Ratio:-}

Data highlights that as per 2001 Census of India, in Uttarakhand the sex ratio of total SC population is 943, which is higher than the national average of 936 for the same category. There are more females per thousand males among Shilpkar. Table below depict the clear picture of sex ratio among some major SCs group in a state.

Sex Ratio among Major SCs (2001 Census).

\begin{tabular}{|c|c|c|}
\hline S. No. & Scheduled Caste & Sex Ratio \\
\hline 1 & All Scheduled Caste & 943 \\
\hline 2 & Shilpkar & 861 \\
\hline 3 & Chamar & 909 \\
\hline 4 & Balmiki & 920 \\
\hline 5 & Kori & 974 \\
\hline 6 & Bajgi & 919 \\
\hline 7 & Dom & 864 \\
\hline 8 & Pasi & 887 \\
\hline 9 & Dhobi & 894 \\
\hline
\end{tabular}

The child sex ratio (0-6 age group) is at 934 for SCs in the state is close to the aggregated figure of 938 at national level for the same category. The child sex ratio among Balmiki (917) and Chamar (888) has been below the state average for SCs.

\section{Educational Level:-}

Education is an important means for bridging the social distance between upper castes and lower castes. Further in a same reference the literacy rate of the SCs population in Uttarakhand has been recorded as $63.4 \%$ which is above the aggregated national figure for SCs $(54.7 \%)$ but far behind the total literacy of the State i.e. (71.60\%).

The table below clearly illustrates the educational level of both male and female of some major SCs of a state. 
Literacy Rate among Nine Major SCs, (2001 Census).

\begin{tabular}{|l|l|l|l|l|}
\hline \multirow{2}{*}{ S. No. } & Scheduled Caste & \multicolumn{4}{l|}{ Literacy Rate in \% (7+ years and above) } \\
\cline { 3 - 5 } & & Total & Male & Female \\
\hline 1 & All Scheduled Caste & $\mathbf{6 3 . 4}$ & $\mathbf{7 7 . 3}$ & $\mathbf{4 8 . 7}$ \\
\hline 2 & Bajgi & 56.3 & 73.4 & 38.7 \\
\hline 3 & Balmiki & 65.5 & 75.6 & 54.4 \\
\hline 4 & Chamar & 59.1 & 72.0 & 43.9 \\
\hline 5 & Dhobi & 68.9 & 78.6 & 57.8 \\
\hline 6 & Dom & 44.6 & 57.2 & 30.7 \\
\hline 7 & Kol & 43.8 & 55.4 & 30.5 \\
\hline 8 & Kori & 53.8 & 65.6 & 40.9 \\
\hline 9 & Pasi & 62.2 & 70.4 & 52.7 \\
\hline 10 & Shilpkar & 67.2 & 83.0 & 51.8 \\
\hline
\end{tabular}

Source: Office of the Registrar General, India, page 3of 5

Among males six communities have literacy above $70 \%$. However, in case of females only four communities have above 50\% literacy rate. Kol caste have recorded the lowest rate overall as well as male and female literacy. As regard to gender gap with $83 \%$ male and $51.8 \%$ female literacy rate, the Shilpkar women are lagging behind from their male counterparts by 31 percentage points.

\section{Health Status:-}

The infant mortality rates (IMR) among scheduled castes and other backwards classes are higher than the rate among those who do not belong to the scheduled caste, scheduled tribe, or other backward classes. There is also a higher rate of anaemia amongst backward communities (Uttarakhand Report, NHFS 3).

\section{Work Participation Rate (WPR):-}

The percentage of SC workers to total population (WPR) is $37.5 \%$, which is slightly lower than the aggregated figure for SCs at national level of $(40.4 \%)$. The representation of SCs in the secondary and tertiary sectors of the economy is extremely low. Though they are mainly engaged in agriculture and allied activities, most of them are landless agricultural labourers who own meagre land holdings. The female WPR at $29 \%$ is lower than their male counterparts $(45.6 \%)$. Majority workers among males are main workers $(75.4 \%)$. On the other hand among females $(56.7 \%)$ are main workers and $(43.3 \%)$ are marginal. A table represent below describe the fact more clearly.

Distribution of Total, Main \& Marginal Workers among SCs (2001 Census).

\begin{tabular}{|l|l|l|l|l|l|l|}
\hline \multicolumn{9}{|l|}{ Percentage of Workers } \\
\hline & Total Workers & Main Workers & Marginal Workers \\
\hline Total & $\mathbf{5 6 9 , 3 0 4}$ & $\mathbf{3 7 . 5 \%}$ & $\mathbf{3 8 9 , 4 6 6}$ & $\mathbf{6 8 . 4 \%}$ & $\mathbf{1 7 9 , 8 3 8}$ & $\mathbf{3 1 . 6 \%}$ \\
\hline Male & 355,734 & $45.6 \%$ & 268,315 & $75.4 \%$ & 87,419 & $24.6 \%$ \\
\hline Female & 213,570 & $29 \%$ & 121,151 & $56.7 \%$ & 92,419 & $43.3 \%$ \\
\hline
\end{tabular}

Source: Office of the Registrar General, India, page 4of 5

Nature and Extent of Atrocities against the Scheduled Castes in Uttarakhand:-

Cases relating to harassment of Scheduled Caste and atrocities are common knowledge. Several examples of atrocities on lower castes may be quoted and most of the offences were found under section 71 (i) (d) for insult on the ground of untouchability. Some of the recent incidences of atrocities took place against them are like The Deccan Herald on $28^{\text {th }}$ July 2006 published the flaming topic that the Dalits were fined for entering the temple in the Jaunsar Bhawar region in a Dehradun district of Garhwal. The Indian Express and many more newspapers and articles reported the most fiery and burning incident occurred recently in October, 2016 in Kadaria village of Bageshwar district where Dalit was beheaded for using flour mill, accused of being 'impure'. These incidents are just snapshots of violence against lower castes. Times of India highlighted as on 01 Sep. 2016 that the 'Crimes against SC, ST increased by $59 \%$ in Uttarakhand'.

According to the National Crime Reports Bureau (NCRB) data the table and graph below clearly figure out that the incidences and rate of crime committed on SCs in the state of Uttarakhand is very less as compare to other states. 
The table represents the crime situation and the crimes committed against SCs during 2001-2011 in India and Uttarakhand (Crime in India).

Incidence and Rate of Crimes Committed against Scheduled Castes in India and Uttarakhand during 20012011.

\begin{tabular}{|c|c|c|c|c|c|}
\hline Year & $\begin{array}{l}\text { Incidences of } \\
\text { Crime in India }\end{array}$ & $\begin{array}{l}\text { \# Estimated Mid- } \\
\text { year population } \\
\text { (in lakh) }\end{array}$ & $\begin{array}{ll}\text { Incidences } & \text { of } \\
\text { Crime } & \text { in } \\
\text { Uttarakhand } & \\
\end{array}$ & $\begin{array}{l}\text { \# Estimated Mid- } \\
\text { year population } \\
\text { (in lakh) }\end{array}$ & $\begin{array}{l}\% \text { Contribution to } \\
\text { All-India Total }\end{array}$ \\
\hline 2001 & 33,501 & $10,270.2$ & 168 & 84.80 & 0.5 \\
\hline 2002 & 33,507 & $10,506.4$ & 99 & 86.76 & 0.3 \\
\hline 2003 & 26,252 & $10,682.14$ & 129 & 88.25 & 0.5 \\
\hline 2004 & 26,887 & $10,856.0$ & 137 & 89.73 & 0.5 \\
\hline 2005 & 26,127 & $11,027.91$ & 99 & 91.19 & 0.4 \\
\hline 2006 & 27,070 & $11,197.75$ & 68 & 92.62 & 0.3 \\
\hline 2007 & 30,031 & $11,365.53$ & 71 & 94.04 & 0.2 \\
\hline 2008 & 33,615 & $11,531.26$ & 42 & 95.43 & 0.1 \\
\hline 2009 & 33,594 & $11,694.4$ & 58 & 96.8 & 0.2 \\
\hline 2010 & 32,712 & $11,857.56$ & 35 & 98.17 & 0.1 \\
\hline 2011 & 33,719 & $12,101.93$ & 32 & 101.17 & 0.1 \\
\hline
\end{tabular}

Source: Crime in India, Reports of 2001-2011, NCRB, Ministry of Home Affairs, Govt. of India. http://ncrb.gov.in. \# Total population including Scheduled Castes

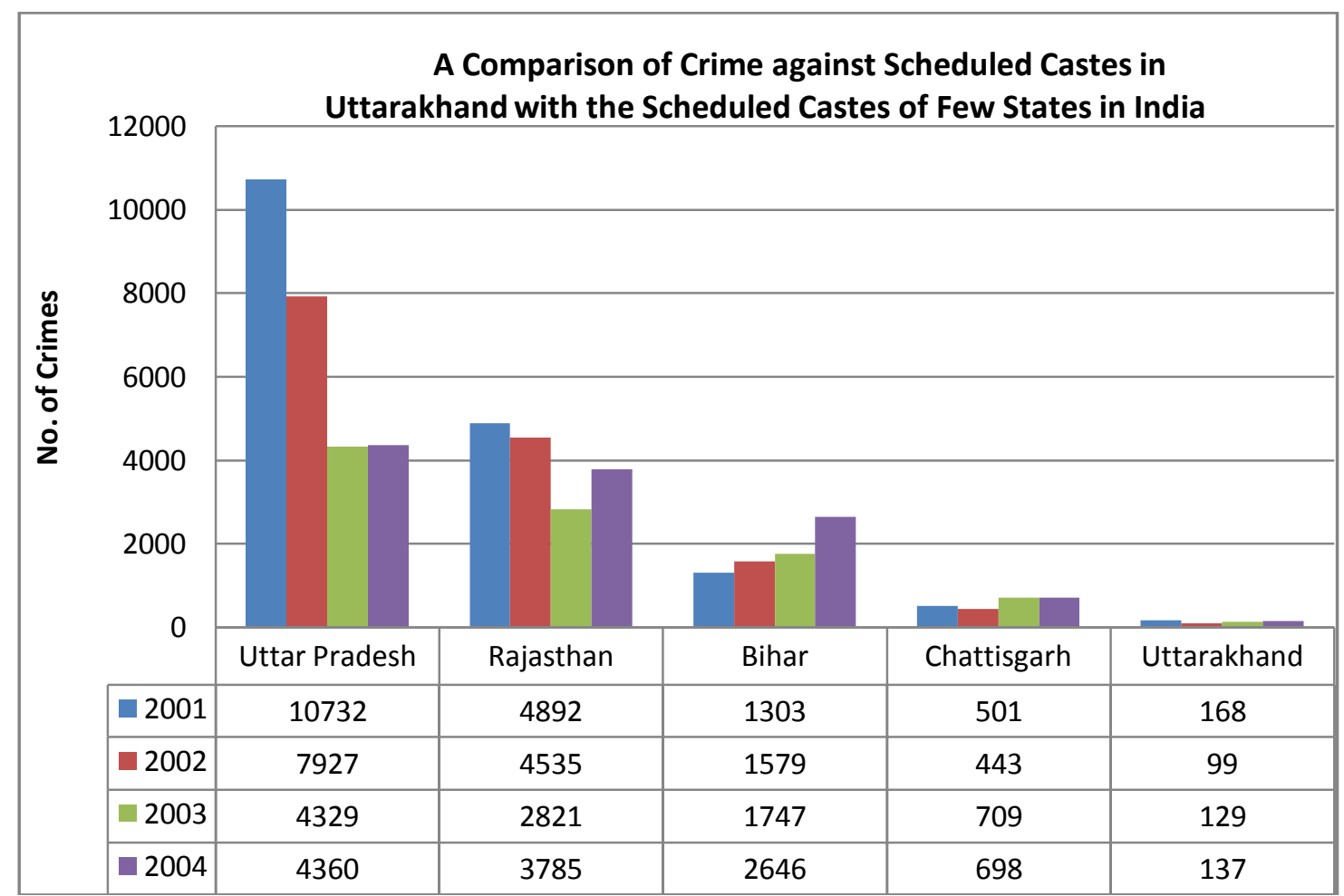

Source: Crime in India 2001-2004, NCRB, Ministry of Home Affairs, Govt. of India

Thus these were some social indicators which show the deprived status of Scheduled Castes in Uttarakhand. They were being excluded in terms of education, health, employment and other opportunities. Caste based discrimination remains wide spread practice across the nation. This religious sanctioned deep rooted discrimination caused marginalisation, social, political and economical exclusion, creates severely poor working conditions and limited access to basic needs and services. After India attained independence the plight of scheduled castes was the primary concern of the social reformers and planners and their efforts shaped into a formidable action. 


\section{Inclusive policies for the excluded group:-}

India is a welfare state. Various affirmative provisions and legislations were laid down in the Constitution of India having sincere commitment towards the inclusive growth of Indian citizen in a form of constitutional safeguards and protective measures that sought to ensure for the deprived group for their overall development and undo the social injustice and all forms of exploitations so that they could form part of the mainstream of the society. The Constitution contains explicit provisions spelling out State obligations towards protecting and promoting the rights and welfare of deprived groups.

The Government of India has been proactive in addressing the exclusion and undertaking policies to foster social and economic empowerment among the poor and excluded groups. In order to facilitate the planning and implementation of such social welfare schemes, Five Year Plans were started immediately after India attained independence. Under these plans several funds were transferred to various head like education, rural development, health, skill trainings, employment, women empowerment, welfare of SCs/ STs, child development and so on.

Various laws, inclusive policies, welfare programmes have been since adopted to address the issues of exclusion, poverty and deprivation. Hence, these schemes sought to exclude the excluded from the magnitude of social deprivation, poverty, isolation, stigmatisation, unemployment and so on. Kummitha in his article concise that the Government of India has enacted 20 point programme launched in 1975 as an integrated programmes to eradicate extreme poverty, raising productivity, reduce income inequalities and removing social and economic disparities etc. The programmes were restructured in 2004 by the UPA government as National Common Minimum Programme under which refined social provisions are mentioned (Kummitha 2015).

Further in a same reference Kummitha briefed some of the significant welfare schemes like Prime Minister Employment Guarantee Scheme (PMEGS) help in generating the employment opportunities through establishment of micro enterprises in both rural and urban areas. The Integrated Rural Development Programme (IRDP) which intended to eliminate poverty, particularly in rural areas and generate self employment. India contemplates to provide just employment and Mahatma Gandhi National Rural Employment Guarantee Act (MNREGA) of 2005 is a move in that direction. Educational development efforts were also made for promoting and enhancing the SCs education at every level under the various schemes and scholarships.

Government policies in relation to the lower caste have evolved over time, it has expanded both in terms of spheres of intervention and strategies and method of implementation. The National Commission for Scheduled Castes monitors and reviews the issues concerning to their welfare. It has wide powers to protect, safeguards and promotes the interests of Scheduled Castes. A Committee under the chairmanship of the Honorable Minister of Social Justice and Empowerment has been constituted for effective coordination to devise ways and means to curb offences of untouchability and atrocities against SCs and STs. Various meetings of Committee were organised for the effective implementation.

In addition to these schemes, the Special Component Plan (SCP) has been initiated for those who are excluded on the base of social backgrounds such as Scheduled Castes and Scheduled Tribes. In 1975 the Government of India decided to allocate funds in the plan outlay to various departments in proportion to the population of SCs and STs in each state to satisfy the constitutional obligation of the government. The 1980s marked a shift in approach with greater focus on special schemes and targeted programmes for the disadvantaged groups. The government introduced the Special Component Sub Plan (SCSP) for the SCs in 1979 (Sixth Five Year Plan).

\section{Conclusion:-}

Discrimination against the lower castes continues to be starkly felt, despite domestic laws and welfare measures aimed at protecting them. Various social indicators like low literacy rate, poor health status, work participation, crime against them indicates their exclusion and marginalization. However, it is widely believed that these wide reaching legislations, schemes and welfare policies have not been implemented in spirit. Various evaluation studies on all these programmes and measures for the integrated development of these excluded groups have brought out the inadequacies of these programmes. The key factor is how development should be articulated and what type of developmental practices should be adopted and applied. We need to advocate the sustainable development measures that can bring about equity in society and not disparity. 


\section{Refernces:-}

1. Thorat, Sukhdeo and Katherine, S. Newman (2007), 'Caste and Economic Discrimination: Causes, Consequences and Remedies', Economic and Political Weekly, XLII (41), pp 4121-4124.

2. Rao, Y. Chinna (2010), 'Social Exclusion in India: Concepts and Context', In 'Exclusion and Discrimination: Concepts, Perspectives and Challenges', edited by Yagati Chinna Rao and S. Karakoti, Kanishka publication, New Delhi, p. 4.

3. Uttarakhand at a Glance (2013-2014), Directorate of Economics and Statistics, Dehradun, Govt. of Uttarakhand.

4. Deccan Herald, $28^{\text {th }}$ July 2006.

5. www.indianexpress.com/article/india/india-news-india/dalit-beheaded-in-uttarakhand-for-using-flour-millaccused-of-being-impure-3070625

6. Crime in India (2001-2010), National Crime Reports Bureau, Ministry of Home Affairs, Government of India.

7. Census of India (2001), 'Data Highlights: The Scheduled Castes', Uttaranchal, pp. 1-5. Retrieved from www.censusindia.gov.in $>$ dh_sc_uttaranchal

8. Statistical Diary (2014-15), Directorate of Economic and Statistical, Govt. of Uttarakhand, Dehradun.

9. Bisht, Khila, Aditi P. Kaur, Satyendra Srivastava and Cyril R. Raphael (2010), 'State Strategy Paper Uttarakhand: Identifying Key Issues', $31^{\text {st }}$ March, Oxfam India, p. 38-39.

10. Kummitha, Rama Krishna Reddy (2015), 'Social Exclusion: The European Concept for Indian Social Reality', Social Change, 45(1), Sage Publications, p. 12-13.

11. Upadhyay, H.C. (1990), 'Harijans of Himalaya: with special reference to the Harijans of Kumaun Hills' Gyanodaya Prakashan, Nainital. 